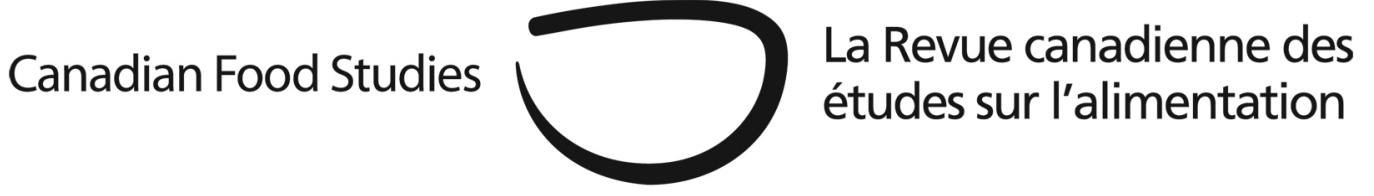

Field Report

\title{
Social economic organizations tackling food insecurity amid a booming economy: The development of the Good Food Junction Cooperative in Saskatoon, Saskatchewan
}

Josie Steeves, University of Saskatchewan

\begin{abstract}
Food insecurity is a phenomenon found around the world, including in developed countries that enjoy a large portion of the world's wealth. Although the economy of the Canadian province of Saskatchewan is currently booming, a large food desert still exists in one low-income area of the city of Saskatoon. This article examines the response of a social economic organization to this issue where government and private industry have failed to act. Although the creation of the Good Food Junction Cooperative (GFJ) is one step in the right direction, there are still many challenges for this organization to overcome food insecurity in this area of the city.
\end{abstract}

Keywords: Food security, social economic organizations, food desert, social policy

Introduction

Saskatoon has received national and international attention regarding its booming economy amidst a lackluster world situation. In 2009, CNN declared Saskatchewan a jobs "hot spot” and the Conference Board of Canada predicted Saskatchewan would lead the country in economic growth (Simon, 2009). While this has led to wealth for many, the growing economy has been financially and socially devastating for others. Poverty has proved unrelenting amid this wave of 
prosperity, as thousands struggle for the basic human need of affordable and accessible food. Like much of the developing and developed world, Saskatoon has long struggled to find a way to ensure its residents have secure access to healthful food. As with other areas of market failure, Social Economic Organizations (SEOs) have responded (Broad, 2011; Karaphillis et al., 2012). The Good Food Junction Co-operative is one such organization. This article provides an examination of how this organization developed to tackle the issue of food insecurity in a neighbourhood in Saskatoon, Saskatchewan.

\section{Context}

The World Health Organization has defined food security as existing "when all people at all times have access to sufficient, safe, nutritious food to maintain a healthy and active life" (World Health Organization, 2015). For a population to be food secure, they must have healthful and culturally acceptable food available to them, the means to have access to sufficient food, and the knowledge to choose and prepare nutritious foods. In 2010, 925 million people were considered undernourished (Food and Agriculture Organization, 2010). This is a global issue (Godfray and Associates, 2010; Koç et al., 1999), with urban food security a growing problem (Mougeot, 1999) in both the developing and developed world.

People living in urban areas are vulnerable to global and local food trends, since they are distanced from food production and rely on commercialized food access. They are limited in their ability to supplement their food supplies with existing agriculture or husbandry infrastructure as those in rural areas may be (Maxwell et al., 2000). The global population is set to reach nine billion by 2050 (United Nations, 2011), with urbanization (United Nations, 2012) and poverty levels rising (Chen \& Ravallion, 2007). Further, food prices around the world are increasing due to environmental and resource trends like soil erosion, climate change, and the increasing use of grain to fuel vehicles (Brown, 2009). All of these factors create a worsening situation that has been referred to as "the greatest humanitarian problem of the next century" (Atkinson, 1995, p. 152), with calls for policy makers and researchers to pay increased attention to urban food security issues (Cohen \& Garrett, 2010; Crush \& Frayne, 2011). Increasingly, SEOs in the international realm are responding to these concerns primarily through promoting urban agriculture (Brown, 2009; Zezza \& Tasciotti, 2010) and local food production (Koç et al., 1999).

\section{Food Security in Canada}

Although Canada is a prosperous nation in many ways, there are four million Canadians with some level of food insecurity (Tarasuk et al., 2014), with urban residents facing more dire situations than rural areas (Lirkpatrick \& Tarasuk, 2011). Urban food security issues have largely been left to the social economy to address. Three main responses from SEOs have been identified: the antipoverty approach (including the use and promotion of food banks), sustainable 
agriculture (such as farmer's markets and people producing their own food) (Power, 1999), and food markets run by volunteers.

Within Canada, the largest urban food security organization is FoodShare Toronto, a nonprofit organization with a vision of "good healthy food for all” (FoodShare, 2015). It runs a number of food education programs, in addition to the Good Food Box (GFB) and Good Food Markets. The GFB was developed as a sustainable solution, and has spread to a number of other communities (Scharf, 1999). GFB delivers local food to specified locations in the city based on advanced orders. The Good Food Markets operate on a similar concept, but offer food in stationary locations around the city at specified times.

Neechie Foods Co-op Ltd., an Aboriginal grocery store in Winnipeg that has been in operation since 1989, offers a different approach. It markets itself as "a community store, based around the principles of an Aboriginal owned and operated worker co-operative” (Neechie Foods Co-op Ltd., 2015). It is run much like a regular co-operative grocery store, but with locally produced and culturally meaningful foods and items.

\section{Food security in Saskatoon}

Food deserts have been defined as "areas of relative exclusion where people experience physical and economic barriers to accessing healthy food” (Reisig \& Hobbiss, 2000, p. 138). These barriers include a lack of access to transportation and a decline in the number of food retail stores in an area. While some areas of Saskatoon have seen investment and growth, the core neighbourhoods west of downtown have not. They experience higher than average societal problems, including declines in available and accessible housing, high poverty rates, and limited access to nutritious food (Hurd, 2012) — leading to the existence of a food desert in the area (Saskatoon Community Clinic, 2008).

In a study of grocery store geography from 1984-2004 in Saskatoon, researchers found the changes had a much larger negative impact on food security in the core neighbourhoods than in other areas of the city (Peter \& McCreary, 2008). By 2004 the number of grocery stores had declined from twelve to five (Peter \& McCreary, 2008). Although the core neighbourhoods were retaining convenience stores, confectionaries, and smaller grocery stores, they are a "poor substitute for the vacancy of major grocers which the majority of shoppers use” (p. 95). These changes have resulted in "substantially reduced access to low cost healthy foods for the highest poverty neighbourhoods in Saskatoon” (p. 98). Since this study was completed only one major store, Giant Tiger, has opened in the area, but it does not carry a wide variety of affordable healthy food options (Hurd, 2012).

Measuring poverty is a process that is contentious at best (OECD, 2011; World Bank, 2015). The Organization for Economic Co-operation and Development (OECD) classify people as poor when "their equivalised household income is less than half of the median prevailing” (OECD, 2011). This allows for poverty to be measured relative to the local circumstances, but is far from a perfect definition. The median income in Saskatoon in 2010 
was \$80,570 (Statistics Canada, 2012). According to the OECD, those living in households making less than $\$ 40,285$ would be considered poor. The average income of families in the core neighbourhoods is less than $\$ 20,000$, while Aboriginal families — of which there is a high proportion - earn on average \$16,000 (Saskatoon Community Clinic, 2008, p. 4). With the lack of affordable food options in accessible locations in the core neighbourhoods, this widespread poverty exacerbates the situation.

\section{Methods}

This case study was completed through a document analysis as described by Bowen (2009). Documents are excellent sources of data to examine phenomena that is otherwise difficult to access (Merriam, 2009). Glaser and Strauss (1967) discussed the similarities between fieldwork and library research:

When someone stands in the library stacks, he is, metaphorically, surrounded by voices begging to be heard. Every book, every magazine article, represents at least one person who is equivalent to the anthropologist's informant or the sociologist's interviewee. In those publications, people converse, announce positions, argue with a range of eloquence, and describe events or scenes in ways entirely comparable to what is seen and heard during fieldwork (p. 163).

This article is based on documentation available in the public domain (primarily through internet sources), reports by the Centre for the Study of Co-operatives (University of Saskatchewan, 2014), and a comprehensive review of the literature. Newsletters, organizational websites, third party reports, and news articles informed this article to provide a well-rounded picture of the GFJ, how it developed, and how it responded to issues of food insecurity in Saskatoon.

\section{Good Food Junction: organizational purpose and history}

In 2001 the Community-University Institute for Social Research (CUISR) looked at how people in the core neighbourhoods gained access to healthful food, and found there was little access to food in general, much less healthful food (Johnson, 2012). Conversations surrounding this and other socio-economic issues in the area began in 2003 between two SEOs: Quint Development, a community-run economic development corporation, and Child Hunger and Education Program Good Food Inc. (CHEP), a Saskatoon organization focused on food security issues. These conversations led to the conceptualization of a holistic community service organization, now known as Station 20 West (Hurd, 2012). The fate of Station 20 West and the GFJ were intertwined. Station 20 West was conceived to include spaces for different community 
organizations, office space for the University, health services, and a grocery store- the Good Food Junction Co-operative (Hurd, 2012). The literature supports this “bottom-up” approach, where the social economy takes responsibility for community concerns instead of waiting for government or the private sector to respond (Amyot et al., 2012; Thompson \& Emmanuel, 2012).

In 2006, the newly formed GFJ Board held a feast and round dance on what was to become the home of the store (GFJ News, 2012). At this point, their vision was a "store that strengthens our community by promoting healthy foods and providing a positive working, learning, and shopping environment” (GFJ News, 2007). GFJ was founded by those who saw a need that could be addressed using a community-based approach, as is the case throughout cooperative history (Bouchard et al., 2006; Fairbairn, 2006). The mission has not changed substantially since that day. Their current objective is to sell good food at competitive prices, maintain a fair and good working environment for employees, sell local when possible, work with other community organizations, and "use a holistic approach to community-based economic and social development” (GFJ, 2015).

\section{Funding}

The GFJ has found funding in conjunction with Station 20 West. Government had committed \$8 million in funding in 2007 (GFJ News, 2007), but a provincial election saw a new government elected, and funding was withdrawn. Due to the commercial nature of the SEO, many saw it as a private industry, and not appropriate for government to intervene. Businesses saw the government involvement creating an "unlevel playing field for private business" (Diamantopulos \& Findlay, 2007, p. 38). As a result, a scaled-down version of the building and the GFJ store was envisioned (GFJ News, 2008a). This meant that the majority of the funding had to be secured through fundraising campaigns and donations. Individuals, families, churches, businesses, and organizations jointly donated millions of dollars for Station 20 West. Fundraising activities were held, including concerts, art auctions, and dances (GFJ News, 2008b). The GFJ also received assistance from the federal Co-operative Development Initiative to hire Ralph Winterhalt as business development manager (GFJ News, 2011). As the owner of several confectionary businesses in Saskatoon, he had been involved as a member of the advisory committee, and later became the Store Manager (GFJ News, 2012). A mortgage was used to fund the remaining amount (GFJ News, 2010). Finally on September 7, 2012, the GFJ opened its doors to the public.

\section{Barriers to the organizational evolution}

The process of achieving this goal was not without challenges — outside of the funding difficulties. Station 20 West and the GFJ had a mandate as a holistic organization for community health and engagement. As a result, they were "now expected by government and the community to be able to meet all the needs of the inner-city. It's a catch-22 and perhaps a good example of 
the limitations of a community economic development (CED) strategy without complementary access to social enterprise infrastructure” (Hurd, 2012, p. 18). Everyone had high expectations for the initiative, but there existed very little formal government or structural support.

It has also been argued that a lack of technical assistance in the development of the store posed a challenge. Quint did not have the necessary expertise, making the development of the GFJ a difficult task. Staff and volunteers were frustrated by the lack of information and awareness of organizational models and best practices. Lastly, due to some reported negative history with Quint, an Aboriginal group claimed that the Station 20 West initiative, and by extension the GFJ, were not inclusive of their needs (Hurd, 2012).

Despite these barriers, support grew for the initiative due to community consultation and involvement. The GFJ Board worked closely with the Grocery People-a subsidiary of Federated Co-operatives - for assistance in the early phases of development, as co-ops are ineligible for membership in the Federated Co-op until they have been established for a number of years (GFJ News, 2007). There was also support and assistance from similar initiatives in other jurisdictions, such as Neechi Food Co-op Ltd. (Hurd, 2012). Then, in 2008 the Saskatoon Co-operative Association voted to give the GFJ their full support (GFJ News, 2008a). After some serious setbacks dealt by government and a lack of a comprehensive CED strategy for the area, organizers were able to move forward, bringing more community support and assistance into the organization.

Incorporation status

The GFJ was initially incorporated as a for-profit co-operative, a similar operating model to Neechie Food Co-op Ltd. In 2009, Station 20 West applied for charitable status (GFJ News, 2009). By Spring 2011, the GFJ Board recommended a change to non-profit to "clarify intentions to the public and alleviate concerns among those who have difficulty supporting a charitable organization (Station 20 West) that would otherwise have been leasing space to a forprofit store” (GFJ News, 2011). This status as a non-profit organization makes GFJ unique; it is different from other food co-operative model in western Canada who run on a for-profit model. Other approaches SEOs take to food security that differ from the GFJ model include food markets, the GFB, and schemes where groups pre-purchase a share of a farmer's produce at an affordable rate (Christensen \& Neil, 2009). Other grocery stores that operate in Canada, like By the Bushel Community Food Co-operative in Peterborough, have limited hours of operation (By The Bushel, 2015). Neechie Food Co-op Ltd. seems to be the most comparable SEO in Canada, but GFJ has an incorporation status adapted to local circumstances. 


\section{Organizational characteristics today}

Today, the GFJ comprises 4900 square feet of space in Station 20 West (GFJ News, 2010), with three full-time and four part-time employees in addition to the Store Manager (Johnson, 2012). GFJ sells shares in the form of lifetime memberships, but as they are incorporated as a nonprofit, there are no dividends to be paid (GFJ News, 2011). Anyone is able to shop in the store. Members are entered into a weekly draw for a fifty dollar gift certificate every time they purchase something at the store (GFJ, 2015b). Members are also asked to make a pledge as to how much they will spend in the store. If they fulfill the pledge, they are entered into draws for prizes (GFJ News, 2012).

\section{Governance model}

A Board of Directors is elected at the Annual General Meeting (GFJ News, 2008a). There are also spots for several organizations such as the Saskatchewan Tribal Council and CHEP (Warren, 2012). All who purchase memberships have voting privileges at these annual meetings, and can sit on a variety of committees such as finance, human resources, membership, and wholesaler relations (GFJ News, 2007). The GFJ makes it very well known that this is a SEO that belongs to the community, and encourages people to become involved in its decision making processes.

\section{Organizational challenges}

The main challenge is obvious: creating a grocery store that community members will use. Even though this is an organization with a strong social mandate, it still needs to operate in a businesslike fashion and recoup costs. Part of this challenge is determining and supplying services the community wants and needs. However, as the store has been scaled down, carrying a multitude of brands and options is a challenge. The community identified national brands as particularly important. The GFJ has potentially developed a solution to this through periodic "warehouse" days where residents can buy specific products in bulk (Hurd, 2012, p. 21). The GFJ has continued to work with residents and research bodies to try to construct an organization that truly reflects the community.

\section{Organizational successes}

The main organizational success in the GFJ story has been opening the store and engaging the community as a whole in the process - an important aspect in SEO success (MacPherson \& Toye, 2011; Findlay et al., 2011). In the face of significant funding and organizational 
challenges, Station 20 West and GFJ were able to rally the community behind them to garner enough support and resources to make the vision a reality: 500 memberships were sold even before the store opened (Warren, 2012). So far, the organization has proven to be successful in their endeavours. However, as the GFJ has been in operation for a short time, it is premature to label it as a complete success.

\section{Conclusion}

Ensuring that all people have access to healthful food is a central tenet of a healthy society. Organizations like the GFJ are initiated by communities to fill a food security gap that private industry and the state do not view as a priority. In essence, GFJ is responding to a larger societal problem: the existence of poverty within a sea of wealth. Although it has only been open as a store for a few months, it originates from a project that was years in the making. If the experience of Neechie Foods Coop Ltd. is an indicator of the future, GFJ is set to see a surge of use and calls for expansion (Neechie Food Co-op Ltd., 2015b). Station 20 West and the GFJ are examples of people working together, regardless of ethnicity, gender, political stripe, and religion. They are testament to community strength and perseverance in Saskatoon.

\section{References}

Akinson, S.J. (1995). Approaches and Actors in Urban Food Security in Developing Countries. Habitat International, 19(2), 151 - 163.

Amyot, S., Downing, R., \& Tremblay, C. (2012). Public Policy for the Social Economy: Building A People-Centred Economy in Canada. In R. Downing (Ed.), Canadian Public Policy and the Social Economy. Victoria: University of Victoria.

Bouchard, M.K., Ferraton, C., \& Michaud, V. (2006). Database on social economy organizations: The qualification criteria. Chaire de recherche en économie sociale. Retrieved from http://www.chaire.ecosoc.uqam.ca/Portals/ChaireEcoSoc/docs/pdf/cahiers/R-2006-03.pdf

Bowen, G.A. (2009). Document Analysis as a Qualitative Research Method. Qualitative Research Method, 9(2), 27-40.

Broad, G. (2011). Respectful Research Relations. Learnings from Communities. In P.V. Hall and I. MacPherson (Eds.), Community-University Research Partnerships: Reflections on the Canadian Social Economy Experience. Victoria: University of Victoria. 
Brown, L.R. (2009). Plan B 4.0: Mobilizing to Save Civilization. New York: W.W. Norton \& Company.

By the Bushel Community Food Co-operative. (2015) By the Bushel Community Food Cooperative. Retrieved from http://www.bythebushel.ca/

Chen, S. \& Ravallion, M. (2007). Absolute Poverty Measures for the Developing World, 1981 2004. World Bank Policy Research Working Paper 4211.

Christensen, C. \& Neil, B. (2009). Feeding the cities - Case studies from Australia, Brazil, USA and Canada exploring the role of urban agriculture and rural family Farms in community food security. Retrieved from http://www.regional.org.au/au/apen/2006/refereed/2/2847_christenson.htm

Cohen, M.J. \& Garrett, J.L. (2010). The food price crisis and urban food (in)security. International Institute for Environment and Development (EERD), 22(2), 467 - 482.

Crush, J.S. \& Frayne, G.B. (2011). Urban food insecurity and the new international food security agenda. Development Southern Africa, 28(4), 527- 544. doi: 10.1080/0376835X.2011.605571

Diamantopulos, M. and Findlay, I.M. (2007). Growing Pains: Social Enterprise in Saskatoon's Core Neighbourhoods. Retrieved from http://usaskstudies.coop/socialeconomy/files/LLL_Final_Reports/Report_CL4_04_SK.pdf

Fairbairn, B. (2006). Co-operative Heritage: Where We've Come From. Centre for the Study of Co-operatives, University of Saskatchewan. Retrieved from http://usaskstudies.coop/CSC\%20Research\%20Reports\%20\&\%20Other\%20Publications/2 006_Coop_Heritage.pdf

Findlay, I.M., Ray, C., \& Basualido, M. (2011). Research as Engagement: Rebuilding the Knowledge Economy of the Northern Saskatchewan Trappers Association Co-operative. In P.V. Hall \& I. MacPherson (Eds.), Community-University Research Partnerships: Reflections on the Canadian Social Economy Experience. Victoria: University of Victoria.

Food and Agriculture Organization of the United Nations. (2010). Global hunger declining, but still unacceptable high. Economic and Social Development Department. Retrieved from http://www.fao.org/docrep/012/al390e/al390e00.pdf

FoodShare. (2015). About Us. Retrieved from http://www.foodshare.net/about-us-2 
Glaser, B. G. \& Strauss, A. L. (1967). The Discovery of Grounded Theory: Strategies for Qualitative Research. Chicago: Aldine Publishing Company.

Good Food Junction. (2015a). About. Retrieved from http://goodfoodjunction.com/e107_plugins/content/content.php?content.10

Good Food Junction. (2015b). Member Benefits. Retrieved from http://goodfoodjunction.com/e107_plugins/content/content.php?content.9

Good Food Junction. (2007). Good Food Junction News, 1(1). Retrieved from http://goodfoodjunction.com/e107_files/downloads/vol.01.iss.02.pdf

Good Food Junction. (2008a). Good Food Junction News, 2(1). Retrieved from http://goodfoodjunction.com/e107_files/downloads/vol.02.iss.01.pdf

Good Food Junction. (2008b). Good Food Junction News, 2(2). Retrieved from http://goodfoodjunction.com/e107_files/downloads/vol\%2002\%20iss\%2002\%20.pdf

Good Food Junction. (2009). Good Food Junction News, 3(1). Retrieved from http://goodfoodjunction.com/e107_files/downloads/vol.03.iss.01.\%20FINAL.pdf

Good Food Junction. (2010). Good Food Junction News, 4(1). Retrieved from http://goodfoodjunction.com/e107_files/downloads/vol.04.iss.01.\%20Final[1].pdf

Good Food Junction. (2011). Good Food Junction News, 5(1). Retrieved from http://goodfoodjunction.com/e107_files/downloads/spring\%20news\%20ltr\%20gfj\%20201 1.pdf

Good Food Junction. (2012). Good Food Junction News, 6(1). Retrieved from http://goodfoodjunction.com/e107_files/downloads/Spring\%202012\%20-\%20final.pdf

Health Canada. (2008). Household Food Insecurity in Canada in 2007-2008: Key Statistics and Graphics. Retrieved from http://www.hc-sc.gc.ca/fnan/surveill/nutrition/commun/insecurit/key-stats-cles-2007-2008-eng.php).

Hurd, E. (2012). Community Conversations about the Good Food Junction Co-operative. Saskatoon, SK: Centre for the Study of Co-operatives, University of Saskatchewan. 
Johnson, L. (2012, September 6). Let The Feast Begin!: Despite Brad Wall, Saskatoon’s Core Finally has a Grocery. Planet $S$. Retrieved from http://www.planetsmag.com/story.php?id=950

Karaphillis, G., Asimakos, S., \& Moore, S. (2012). Financial Social Economy Organizations. In R. Downing (Ed.), Canadian Public Policy and the Social Economy. Victoria: University of Victoria.

Kirkpatrick, S.I. \& Tarasuk, V. (2011). Housing Circumstances are Associated with Household Food Access among Low-Income Urban Families. Journal of Urban Health, 88(2), 284296. doi: 10.1007/s11524-010-9535-4

Koc, M., MacRae, R., Mougeot, L.J.A., \& Welsh, J. (1999). Introduction. In M. Koc, R. MacRae, L.J.A. Mougeot, \& J. Welsh (Eds.), For Hunger-proof Cities: Sustainable Urban Food Systems. Ottawa: International Development Research Centre.

MacPherson, I. \& Toye, M. (2011). Why Staying the Course is Important: Reflecting on the Community-University Relationships Associated with the Canadian Social Economy Research Partnerships, 2005-2011. In P.V. Hall and I. MacPherson (Eds.), CommunityUniversity Research Partnerships: Reflections on the Canadian Social Economy Experience. Victoria: University of Victoria.

Maxwell, D., Levin, C., Armar-Klemesu, M., Ruel, M., Morris, S., Ahiadeke, C. (2000). Urban Livelihood and Food and Nutrition Security in Greater Accra, Ghana. International Food Policy Research Institute. Retrieved from http://www.who.int/nutrition/publications/foodsecurity/livelihoods_foodsecurity ghana.pdf

Merriam, S. B. (2009). Qualitative research: A guide to design and implementation. San Francisco, CA: Jossey-Bass.

Mougeot, L.J.A. (1999). For Self-reliant Cities: Urban Food Production in a Globalizing South. In M. Koc, R. MacRae, L.J.A. Mougeot, \& J. Welsh (Eds.), For Hunger-proof Cities: Sustainable Urban Food Systems. Ottawa: International Development Research Centre.

Neechie Foods Co-op Ltd. (n.d.a). About Us. Retrieved from http://neechi.ca/about/

Neechie Foods Co-op Ltd. (n.d.b). Neechie Commons. Retrieved from http://neechi.ca/neechicommons/ 
OECD. (2011). Society at a Glance, 2011 - OECD Social Indicators. Retrieved from http://www.oecd.org/els/soc/societyataglance2011-oecdsocialindicators.htm

Peters, E.J. and McCreary, T.A. (2008). Poor Neighbourhoods and the Changing Geography of Food Retailing in Saskatoon, Saskatchewan, 1984 - 2004. Canadian Journal of Urban Research, 17(1), pp. $78-106$.

Power, E.M. (1999). Combining Social Justice and Sustainability for Food Security. In M. Koc, R. MacRae, L.J.A. Mougeot, \& J. Welsh (Eds.), For Hunger-proof Cities: Sustainable Urban Food Systems. Ottawa: International Development Research Centre.

Reisig, V.M.T. and Hobbiss, A. (2000). Food deserts and how to tackle them: a study of one city’s approach. Health Education Journal, 59, pp. 137 - 149.

Scharf, K. (1999). A Nonprofit System for Fresh-produce Distribution: The Case of Toronto, Canada. In M. Koc, R. MacRae, L.J.A. Mougeot, \& J. Welsh (Eds.), For Hunger-proof Cities: Sustainable Urban Food Systems. Ottawa: International Development Research Centre.

Simon, Mallory. (2009, March 4). Saskatchewan a jobs 'hot spot' in Canada. CNN.com. Retrieved from http://articles.cnn.com/2009-03-04/world/saskatchewan.economy_1 saskatchewan-province-unemployment?_s=PM:WORLD

Statistics Canada. (2012). Median total income, by family type, by census metropolitan area. Retrieved from http://www.statcan.gc.ca/tables-tableaux/sum-som/101/cst01/famil107aeng.htm

Thompson, M. (2012). Financial the Social Economy. In M. Thompson and J. Emmanuel (Eds.), Assembling Understandings: Findings from the Canadian Social Economy Research Partnerships, 2005-2011. Victoria: University of Victoria.

Thompson, M. \& Emmanuel, J. (2012). Organizational Governance and Capacity. In M. Thompson and J. Emmanuel (Eds.), Assembling Understandings: Findings from the Canadian Social Economy Research Partnerships, 2005-2011. Victoria: University of Victoria.

Tarasuk, V., Mitchell, A., Dachner, N. (2014). Household food insecurity in Canada, 2012. Toronto: Research to identify policy options to reduce food insecurity (PROOF). Retrieved from http://nutritionalsciences.lamp.utoronto.ca 
United Nations. (2011). World Population Prospects, The 2010 Revision: Highlights and Advance Tables. Retrieved from http://esa.un.org/wpp/Documentation/pdf/WPP2010_Highlights.pdf

United Nations. (2012). World Urbanization Prospects: The 20011 Revision. Retrieved from http://esa.un.org/unup/pdf/WUP2011_Highlights.pdf

Warren, J. (2012, September 10). Good food junction opens. The StarPhoenix. Retrieved from http://www2.canada.com/saskatoonstarphoenix/news/story.html?id=c1be15bf-c5f3-457aa85d-21255f7cc0f7

World Bank. (2015). Measuring Poverty. Retrieved from http://web.worldbank.org/WBSITE/EXTERNAL/TOPICS/EXTPOVERTY/EXTPA/0,,con tentMDK:20202198 menuPK:435055 pagePK:148956 piPK:216618 theSitePK:430367, $\underline{00 . h t m l}$

World Health Organization.. (2015). Food Security. Retrieved from http://www.who.int/trade/glossary/story028/en/

Yin, R.K. (2009). Case Study Research: Design and Methods (2 ${ }^{\text {nd }}$ Ed.). Los Angeles: SAGE.

Zezza, A. \& Tasciotti, L. (2010). Urban agriculture, poverty, and food security: Empirical evidence from a sample of developing countries. Food Policy, 35, 265 - 273. 